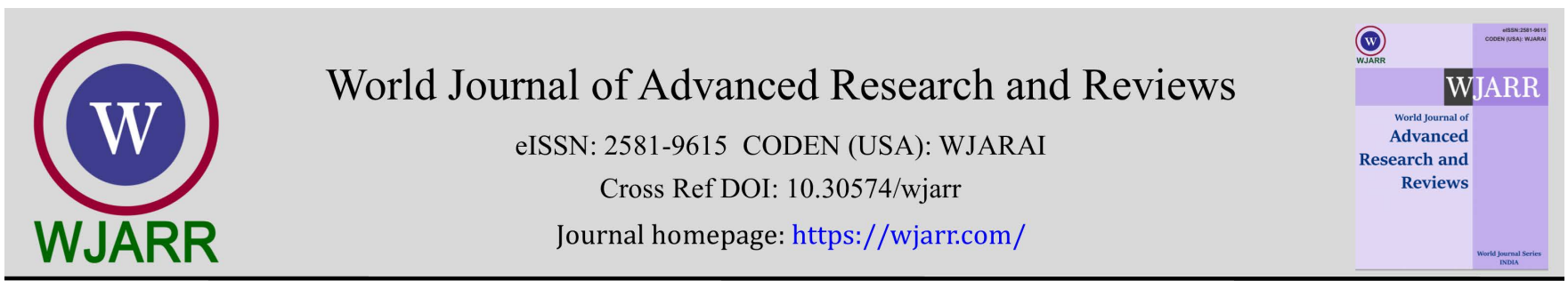

(RESEARCH ARTICLE)

Check for updates

\title{
Zooplankton composition and abundance from Nideban Reservoir, Udgir Dist. Latur
}

\author{
Dhaswadikar Usha Sitaram* \\ Dept. of Zoology, Shri. Hawagiswami College, Udgir Dist. Latur.
}

World Journal of Advanced Research and Reviews, 2021, 12(03), 151-154

Publication history: Received on 03 November 2021; revised on 06 December 2021; accepted on 08 December 2021

Article DOI: https://doi.org/10.30574/wjarr.2021.12.3.0640

\begin{abstract}
Zooplanktons are the microscope free swimming organisms of aquatic system. There are represented by a wide array of taxonomic groups of which the members belonging to protozoa, Rotifera, Cladocera and Copepoda are most common and often dominate the entire communities. They have many remarkable features which hamper their predation by higher organisms. The members of Zooplankton community are important for their role in trophic dynamics, energy transfer in the aquatic ecosystem. They provide food for fishes in the water bodies and play a major role in the fish production. The zooplankton community was studied by monthly samples taken from Oct. 2018 to Feb. 2019 . The reservoir water is used for agriculture and fishery activities.
\end{abstract}

Keywords: Zooplankton: Nideban: Reservoir: Protozoa

\section{Introduction}

Zooplanktons are microscopic animals that act as primary and secondary links in the food webs at all aquatic ecosystems. They feed on phytoplankton which directly provide food source for larval vertebrates and invertebrates as well as related to the growth of juvenile and large fish. They are also important component in the transfer of energy from primary producers to higher trophic levels such as fish. Zooplanktons having limited powers of locomotion and these animals capable of swimming independently. Fresh water zooplanktons are dominate by four major groups of animals. Protozoans, rotifers and two subclasses of the crustacean i.e. cladocerans and copepods. Many protozoan's feed on bacteria and detritus particles generally which are not utilized by large zooplanktons. Most of the rotifers are sessile and are associated with the littoral zone, some are completely planktonic. These are non-predatory, omnivorous feed on bacteria, small algae and detritus organic matter.

Most cladocerans are small and have distinct head, the body is covered by a bivalve carapace. Copepods consist of two major groups, the calanoids and the cyclopoids. These two groups are separated on the basis of body structure, length of antennae and legs. Several authors have worked on zooplankton community. Ganpati (1943), studied on the distribution of zooplankton in water bodies near Madras. The composition and dominance of zooplankton species play significant role in functioning of fresh water ecosystem. The present study has been undertaken to determine the zooplankton composition and abundance in the study site.

\section{Material and methods}

Study site Nideban reservoir is situated at Udgir, Dist.Latur of Maharashtra State. The reservoir length is 333 meter, height $29.65 \mathrm{~m}$. The water plankton samples were collected from different three sites monthly by using plankton net having mesh size of 50u during the year Oct. 2018 to Feb.2019. The 100 liter water sample was filtered through the plankton net in $100 \mathrm{ml}$ sampling bottle attached to the plankton net. The collected plankton sample was preserved in

\footnotetext{
* Corresponding author: Dhaswadikar Usha Sitaram

Dept. of Zoology, Shri. Hawagiswami College,Udgir Dist.Latur.

Copyright (C) 2021 Author(s) retain the copyright of this article. This article is published under the terms of the Creative Commons Attribution Liscense 4.0.
} 
$4 \%$ formalin. The quantitative and qualitative analysis of zooplankton was carried out in the laboratory with the help of Sedgwick rafter cell counting chamber. The samples were kept for setting for a period of 48 hrs. The zooplanktons were identified as described by Needam and Needam (1962), Tonapi (1980), Trivedi and Goel(1984). The identified zooplanktons were also presented in percent composition and population dynamics.

\section{Results}

Zooplankton composition-A checklist of zooplankton species occurred at the study sites in Table 1

Table 1 Zooplankton Species Checklist and Distribution at Study Sites during period (Oct. 2018 to Feb. 2019)

\begin{tabular}{|l|l|l|l|l|l|}
\hline \multirow{2}{*}{} & \multirow{2}{*}{ Family } & \multirow{2}{*}{ Species } & \multicolumn{3}{|c|}{ Study Cites } \\
\cline { 4 - 7 } & & & $\mathbf{1}$ & $\mathbf{2}$ & $\mathbf{3}$ \\
\hline Rotifera & \multirow{2}{*}{ Branchionidae } & Branchionus angularis & + & - & - \\
\hline & & Branchionus forficula & - & + & + \\
\hline & & Branchionus quadridentatus & - & - & - \\
\hline & & Branchionus nilsoni & + & + & - \\
\hline & Lepadellidae & Lepadella spe & - & - & + \\
\hline & & Colurella uncinata & + & + & + \\
\hline & Lecandiae & Lecane bulla & + & + & + \\
\hline & & Lecane hamata & + & + & + \\
\hline & & Lecane laterails & + & + & + \\
\hline & & Lecane luna & + & + & - \\
\hline & Notommatidae & Notommato spe & + & + & + \\
\hline & & Scardium spe & + & - & - \\
\hline & & Diaphanosoma sarsi & + & + & + \\
\hline & & Diaphanosoma spe & - & - & - \\
\hline & & Adult & + & + & + \\
\hline & & Nauplii & + & + \\
\hline
\end{tabular}

\subsection{Zooplankton Abundance}

Zooplankton abundance throughout the study period is shown in Fig. I. The highest zooplankton abundance (160 ind/L) was recorded in the month of November 2018 while the lowest abundance (20 ind/L) was noticed in the month of February 2019. All zooplankton species occurred at the highest abundance in November 2018 while lowest in February 2019. In which zooplankton species of rotifers were dominated over others followed by copepod and cladocera.

Fig. 2 shows the percentage of zooplankton abundance of each study sites during study period. Rotifera shows the highest abundance at all sampling stations compared to the other groups. The highest abundance of Rotifera occurred at site 1 (140 ind/L), copepod at site 2 (15ind/L) and Clodocera at site 3 (10 ind/L) 


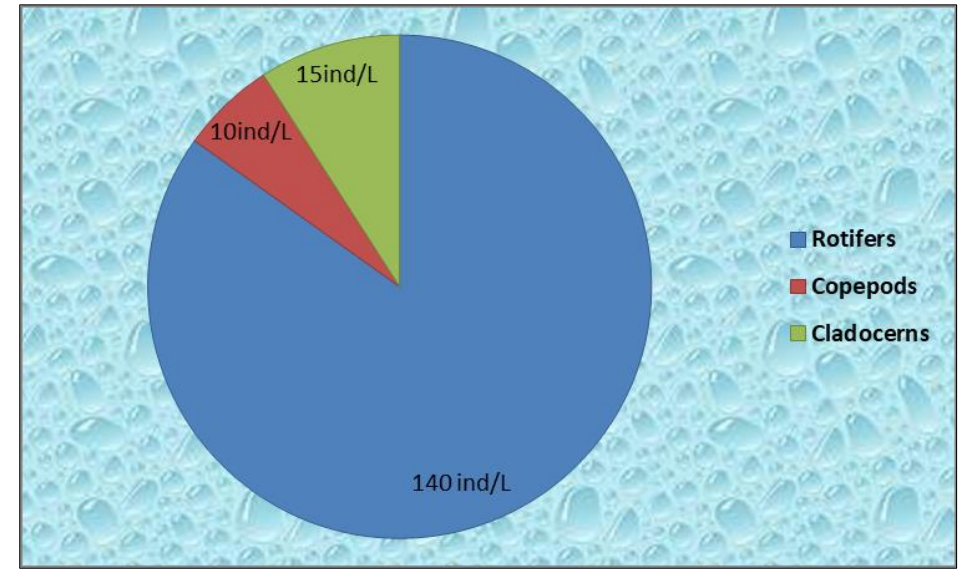

Figure 1 Percentage of Zooplankton Abundance of Each Study Sites during period (Oct. 2018 to Feb. 2019)

\section{Discussion}

The present study showed that rotifers dominated in terms of species composition and abundance. The high number of Rotifers in fresh water bodies is due to their less specialized feeding habits, high fecundity and short development rates.

Cladocera and copepod were observed in lower composition and abundance compared to Rotifers. This is due to predation by fishers and the changes in chemical characteristics of the water condition. The number of zooplankton species recorded in study site third was lower than remaining two study sites. The differences of species number among the studies probably due to the differences in terms of sampling frequency, small sampling methods during the sampling periods.

In the present study, zooplankton abundance was correlated with water transparency. This is good evidence that an increase in the water transportation leads to an increase the zooplankton communities. Low composition is a signal that the communities are under stress conditions.

\section{Conclusion}

The composition and abundance of zooplankton from all three study sites showed the presence of three groups: Rotifera, clasdocera and copepoda from these rotifers are more in abundance, followed by cladocerans and copepods. The dominance of zooplankton species is highly variable in different types of study sites according to nutrient levels, predator and environmental factors.

\section{Compliance with ethical standards}

\section{Acknowledgments}

I'm thankful to principal of our college for his support during study work. I'm also thankful my son for his help during collection of sample at study sites.

\section{References}

[1] RS Stemberger. "An inventory of rotifer species diversity of northern Michigan inland Lakes," Archiv for Hydrobiologie. 1990; 118: 283-302.

[2] SK Mukhopadhyay, B Chattopadhyay, AR Goswami, A. Chatterjee, "Spatial variations in zooplankton diversity in waters contaminated with composite effluents," J. Limnol. 2007; 66: 97-106.

[3] D Rissik, D van Senden, M Doherty, T Ingleton, P Ajnani, L Bowling, M Gibbs, M Gladstone MT Kobayashi, I Suthers, W Foroneman. "Plankton-related environmental and water-quality issues." In Plankton, a guide to their ecology and monitoring for water quality, Is ted. I.M. Suthers, D. Rissik, Eds. Melbourne: CSIRO Publishing. 2009; 39-72.

[4] RW Pennak. Freshwater invertebrates of the United States. New York. John Wiley \& Sons, Inc. 1978; 1-803. 
[5] BAG Idris. Freshwater zooplankton of Malaysia (Crustacea Cladocera). Malaysia: Universiti Pertanian Malaysia, Serdang, Selangor. 1983; 10-151.

[6] RJ Shiel. A guide to identification of rotifers, cladocerans and copepods from Australian inland waters Albury: Cooperative Research Centre for Freshwater Ecology, Murray-Darling Freshwater Research Centre. 1995; 1-142

[7] E Ogbeigbu. Biostatistics, a practical approach to research and data handling. Nigeria: Minex publishing Company Limited, Benin City Nigeria. 2005; 153-155.

[8] JH Zar. Biostatistical analysis. New Jersey: Prentice Hall, Upper Saddle River. 1999; 395-398.

[9] JD Allan. “Life history patterns in zooplankton,” American Naturalist. 1976; 110: 165-176.

[10] IF Neves, D Rocha, KF Roche, AA Pinto. "Zooplankton community structure of two marginal lake of river (Cuiaba) (Mato, Grosso, Brazil) with analysis of rotifer and Cladocera diversity," Braz. J. Biol. 2003; 63(2): 329-343.

[11] JF Pankow, Aquatic Chemistry Concepts. Chelsea: Lewis Publishers. 1991; 109-127.

[12] HY Zakaria, AA Radwan, MA Said, "Influence of salinity variations on zooplankton community in El-Mex Bay, Alexandria. Egypt,” Egypt. J. Aquat. Res. 2007; 33(3): 52-67.

[13] NZ Zulikha, FM Yusoff, J Nishikawa, A Arshad, HM Matiasestuary. "Mesozooplankton composition and abundance in a trophical estuary during monsoon season," Journal of Fisheries and Aquatic Science. 2013; 8: 430-440.

[14] MC Dash. Fundamental of Ecology. New Delhi. Tata McGraw Hill. 2003; 516-527.

[15] SM Frutos, AS Poi de Neiff, G Neiff. "Zooplankton abundance and species diversity in two lakes with different trophic states (Correintes, Argentina)," Acta Limnol Bras. 2009; 21(3): 367-375. 